\title{
FRS2 wt Allele
}

National Cancer Institute

\section{Source}

National Cancer Institute. FRS2 wt Allele. NCI Thesaurus. Code C52381.

Human FRS2 wild-type allele is located in the vicinity of $12 q 15$ and is approximately $105 \mathrm{~kb}$ in length. This allele, which encodes fibroblast growth factor receptor substrate 2 protein, plays a role in the regulation of both fibroblast growth factor and nerve growth factor intracellular signaling pathways. 